\title{
Research and Analysis
}

\section{Political Parties and Web 2.0: The Liberal Democrat Perspective}

\author{
Darren G. Lilleker \\ Bournemouth University \\ Mark Pack \\ Mandate Communications \\ Nigel Jackson \\ University of Plymouth
}

Political parties have been criticised for their limited use of interactivity via their Internet presences, largely it is suggested because they seek to control their online messages. This article will consider interactivity from the perspective of a political party, the Liberal Democrats, using their Freedom Bill online campaign as a case study. We suggest that the Liberal Democrats use 'weak interactivity' because of internal policymaking concerns, and their belief that as a political party they are promoting their ideas, not co-creating a new product. Thus we suggest interaction should be closer to a formal consultation than a face-to-face dialogue.

\section{Introduction}

It has been suggested that the evolution of campaigning to a professional, postmodern model has been driven by changes in the modes by which parties can communicate with the wider public (Norris, 2000; Plasser, 2002). As society moves from an analogue to a digital era, with audiences being increasingly fragmented in their use of a range of media, political communication enters a very new communication environment. In particular, political strategists, party leaders and elected representatives are assessing the communicative potential offered by the Internet, and the relative advantages and disadvantages of embracing more interactive modes and styles.

While UK political parties have slowly increased their use of the Internet as a communication channel, a series of external factors have shaped this. Initially, political parties were influenced by a bandwagon effect (Ward and Gibson, 1998); as their competitors had an online presence they felt forced to follow suit. Gradually, other more positive examples shaped their use, such as the innovative use of the Internet as a mobilisation tool by Howard Dean (Lusoli and Ward, 2005; Sommer, 2003; Williams et al., 2005). A more recent and potentially more influential example is the campaign of Barack Obama, considered the most 'interactive'

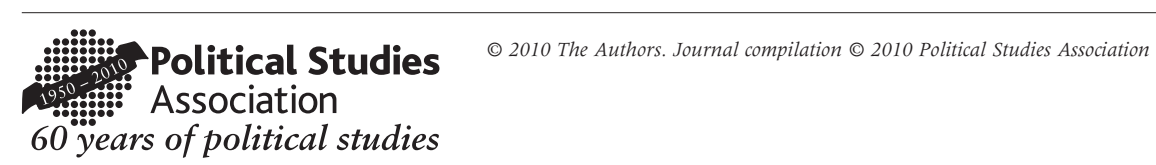


in history (Greengard, 2009; Stirland, 2008), at least in terms of its leadership and structure, even if much of the technology had been pioneered by others. While both examples are from election campaigns, they provide hard data suggesting the effectiveness of complementing offline work with an online campaign. In addition, UK political parties have developed their own experience and evidence, based on their Internet activities which now stretch back over a decade.

Commentators have since the early 1990s suggested that the Internet has the potential to enhance the relationship between politicians and citizens (Rheingold, 1993; Stone, 1996). While empirical data have not supported such an optimistic view (Coleman, 2001; Newell, 2001; Ward and Gibson, 1998), Web 2.0 applications such as blogs, social networking sites and file-sharing sites have significantly raised hopes again. Matthew Hindman (2008) suggests that the Internet empowers only a small elite, not all citizens, and one school of thought suggests that the level of interactivity online will always be limited by political parties because inherently they seek to control their messages both offline and online (Stromer-Galley, 2000; Tedesco, 2007). Jackson and Lilleker (2009a and 2009b) conclude that politics has not fully embraced the architecture of participation inherent within Web 2.0. They found that while some MPs and parties provide space for public participation, contributions are often closer to graffiti than conversation as the voice of the host is seldom present. Similarly, across some online presences, it seems parties are allowing visitors to 'let off steam' and vent their anger at aspects of the party, but at the same time restricting visits through offering little added value. Their overall conclusion is that parties are trying to adapt the tools for promotional purposes, and create an interactive product on their websites, such as widgets, click-thrus and sign-up mechanisms, as opposed to supporting a conversational interactive process. This article will assess why this might be the case by considering the use of interactive tools, not from the perspective of outside commentators, but from that within a political party, using the Liberal Democrats as a case study. ${ }^{1}$

\section{The case for adopting interactive technologies}

Scott Wright (2008) notes that any move towards interactivity represents a shift away from a top-down model of political communication. It is movement in this direction, and an embracing of Web 2.0 sites and tools, which is seen as being important in re-engaging the masses with politics. Advocates of a political adaptation to Web 2.0 argue that the provision of an architecture of participation $\left(\mathrm{O}^{\prime}\right.$ Reilly, 2005) can break down social boundaries and hierarchies and place the represented and representatives side by side in an open forum (for a review see Jackson and Lilleker, 2009a). While conceptually different in some ways, scholars look to a future of e-democracy, where key aspects of democratic participation take place online (Coleman, 2005a and 2005b), and e-representation, where citizens and their representatives can build links based on actual geographic connections or based around policy areas and interests (Jackson and Lilleker, 2009b).

UK political parties play a functional purpose for the political system by developing ideas, mobilising support, recruiting political leaders and enhancing parliamentary government (Garner and Kelly, 1998; Ingle, 2008). However, the ultimate purpose 
of parties' existence is to gain and keep power, or at least influence the holders of power (Schattschneider, 1942). From this context come the possible motivations for using interactive online tools, including:

- winning elections;

- enhancing the relationship between elected representative and elector;

- helping build party support;

- mobilising support (people and funds); and

- helping to develop policy.

There are other motivations for using these tools - such as a more altruistic desire to have a healthy democracy, regardless of whether or not extra votes need to be won, or a desire to build up party support with an eye to other future elections, such as local council elections. However, within an era of the permanent campaign we suggest that the prime purpose of communication is to help win elections, or to acquire resources (money, helpers) which will in turn be used to gain votes. Depending on the party and the contest, winning at elections may equate to a national vote-maximising approach, or it may equate to a seat-maximising approach based on a set of target seats. At the same time, parties have been concerned that statements made, perhaps hastily, online could be seized on by opponents. There is also awareness that Internet-savvy users may find a party's online attempts amateurish. This leads to a potentially complex situation where parties use the Internet to try and gain votes but also seek to avoid losing votes through either what they say online or how they use the Internet.

While the Internet has been argued to have the potential to revolutionise citizen engagement (Norris, 2001), the politics-as-usual hypothesis (Margolis and Resnick, 2000) suggests that inequalities offline in terms of resources and access to the media lead to inequalities online. The largest parties, Labour and the Conservatives, should be the most likely to dominate online. The smaller parties, both with and without parliamentary representation, should be less likely to use the Internet. The equalisation hypothesis (Bimber, 1998; Gibson and Ward, 1997; Jackson, 2007) contends that the Internet can be used as an effective communication channel by smaller parties. Trying to level the playing field with the two larger parties could be a plausible motive for why the Liberal Democrats might be early adopters of the Internet. To gain media coverage, reach voters directly and possibly win target seats, the Liberal Democrats use those tools and techniques that might give them an advantage. Certainly, research suggests that at the level of both party and individual MPs, the Liberal Democrats have been at the forefront of using new technologies (Coleman, 2001; Jackson, 2003; Ward and Gibson, 1998; Ward and Lusoli, 2005).

The Liberal Democrats are an interesting case precisely because of their mixed position within the political system. They have access to power in local councils and have had access to power in national assemblies, but not in Whitehall. Yet their number of MPs (63) gives them some influence in parliament in terms of access to parliamentary procedures. As a third party they have greater freedom in which to manoeuvre, but as the media takes them more seriously, especially in the run-up to a general election, they face similar pressures to those of the two main parties. Such pressures are set within a context of the Liberal Democrats being seen as a serious player in election contests. Hence, of the three main parties the Liberal Democrats 
probably have the greatest ability to innovate, but the context is the same for them as with other parties, if perhaps with fewer resources at their disposal.

\section{The Liberal Democrats' Freedom Bill}

We now turn to a case study to seek to assess whether the limited use of interactivity by political parties is due to a fear of losing control of their messages (Jackson and Lilleker, 2009a; Stromer-Galley, 2002; Tedesco, 2007), or whether an alternative explanation is possible for these apparent shortcomings. As noted above, the Liberal Democrats have a motive to experiment with communication technologies, possibly greater freedom to do so and a track record as an Internet-savvy party.

Our case study is the Liberal Democrats' online activity around their Freedom Bill campaign in 2009. This activity was set in a context of the Liberal Democrats' key target audiences for their online activities as: ${ }^{2}$

1. the media;

2. existing members and helpers;

3. would-be members and helpers;

4. pressure groups and other specialist interests; and

5. floating voters.

The prime goal of the Liberal Democrats' online presence was to influence the offline public debate via the media, as media coverage of the party's online activities frequently reached audiences several orders of magnitude greater than the direct online audience. In terms of individual citizens, there is a clear divide in priority between building relationships with activists, members and supporters, and reaching unaligned voters, particularly as unaligned voters in Liberal Democrat target or vulnerable seats are a very small proportion of the overall electorate and tight geographic targeting is hard to achieve online. Interaction is more likely to be encouraged with the highest priorities - the media, activists and core voters - rather than undecided voters.

The Freedom Bill campaign was launched by the Liberal Democrats on 25 February 2009, with the centrepiece of the campaign being a new website, http:// freedom.libdems.org.uk. The concept was a repackaging and extension of a previous policy initiative by Nick Clegg before he became party leader. First called the Great Repeal Act and then the Freedom Bill, Nick Clegg's initiative sought to draw together different policy proposals for strengthening civil liberties and individual freedoms into one draft piece of legislation, providing a simple message to communicate rather than a range of detailed ideas.

The party's traditional policymaking processes had already set the broad direction for the party in this area and both announcements from MPs and motions at conference had specified some detailed items previously. The Freedom Bill campaign did, however, still contain some policymaking objectives, by looking to solicit advice (though not ceding decision-making) on what should be prioritised by inclusion in the Bill and advice on the details of how the proposals should work.

The 2009 Freedom Bill website proclaimed: 
'The Liberal Democrats are determined to resist the slow death by a thousand cuts of our hard-won British liberties. Some of the changes detailed here may seem small in themselves but taken together they cumulate to a colossal loss of personal freedom in less than two decades. George Orwell's 1984 was a warning, not a blueprint. Yet the Big Brother society is growing. Our forebears who fought so hard for the rights we have had stripped away would be shocked at what we've lost.

That is why we have published our Freedom Bill, detailing how we intend to roll back the draconian laws passed by successive Labour and Conservative administrations. This draft Bill is the first time a major political party has brought all of the laws which have undermined civil liberties together in one piece of legislation so that they can be easily repealed. We have called it the Freedom Bill because if the measures within it were all repealed it would represent the greatest victory for freedom in Britain in the last twenty years'.

A draft bill was published on the website, with 20 clauses - one each for the areas selected by the party as being its priorities in this area such as control orders, ID cards and CCTV.

The site offered interactivity in the following ways:

1. Each draft clause was published in full with the ability for people to post up comments on the clause with a light-touch moderation scheme. (Robust criticisms and disagreements were allowed to appear. Only comments that veered into the abusive or vulgar were moderated.)

2. A general discussion thread on the concept of the Bill, with the ability for people to post up comments on the clause with a light-touch moderation scheme.

3. An online quiz to test people's knowledge about civil liberties matters.

4. A petition for people to sign.

5. An e-mail news list for people to join.

6. A Facebook group, including a wall where people could post up comments with a light-touch moderation scheme.

7. A Facebook version of the quiz.

8. Each news story added to the site also allowed people to post up comments with a light-touch moderation scheme, and the stories were available via an RSS feed for easy republishing elsewhere.

In addition, options 4, 5 and 6 all resulted in the party gathering data that were used for follow-up messages, extending the communication with people beyond the website. The site's data protection terms also allowed the party to keep and use this data for other future campaigns. These terms were not unique to the campaign but are a common feature of online Liberal Democrat initiatives, which seek to add data to the party's existing multi-purpose records.

However, the site did not offer the full range of interactivity possible within Web 2.0 applications. For example, there was no facility for people to vote for/against individual proposals, or to submit their own new clauses (except via posting a comment on the general thread). These limitations, though, reflect a deliberate decision by the Liberal Democrats, which was rooted in two much wider questions:

1. Should a political party tell the public what it believes, or should it ask the public what it wants? 
2. How can you have a democratic policymaking process in a party if you give policymaking power to the public?

Neither question is new to the Internet, or even to the computer age, but choices over online interactivity can only be understood in the context of them both.

For the Freedom Bill, the Liberal Democrats deliberately chose a narrow but deep area of consultation and interactivity. The party wrote the 20 clauses for the Bill and sought both general feedback on the basic ideas outlined and detailed feedback on each clause. Indeed, one of the clauses, on a public interest defence for whistleblowers, was rewritten shortly after the site's launch following detailed comments about its wording. The new version was appended with the comment: 'we've updated the original draft of this clause following feedback. Many thanks for all your suggestions which helped improve $i t^{\prime}{ }^{3}$

The launch received some national media coverage and many local Liberal Democrat associations publicised the Bill, but there is limited evidence that the website reached beyond these target audiences. In terms of interaction with the Freedom Bill website, there were 316 comments on the general discussion of the Bill and 192 comments on specific clauses of the Bill. In addition, the Facebook Group had 2,534 members. These numbers suggest that the consultation process allowed the party to refine its ideas, without necessarily reaching a wider public. The Freedom Bill was probably most successful at engaging with the party membership.

The party used the consultation process like a government White Paper by essentially saying: 'This is what we believe overall; now help us get the details right'. This necessarily restricts the scope for interaction, but the party's stance was to put to the public its overall beliefs and then ask for comment on the details, not the principles underlying the consultation document. If ultimately a party's policy is for its members to control via its own policymaking process, this provides a major limit on what online interactivity can cover.

\section{Discussion and conclusion}

The critique of political parties suggests that the lack of public interaction is explained, by empirical research, as a result of nervousness within campaign teams (Jackson and Lilleker, 2009a; Stromer-Galley, 2000; Tedesco, 2007). This approach suggests that for parties the key concern is a lack of control, and a breakdown in the uniformity and clarity of their message. If discussion takes place publicly, this shapes future user experiences and could affect the integrity of the image of the party as a brand. However, our case study of the Liberal Democrats' Freedom Bill suggests that looking out from inside a party there is a different perspective.

While the Freedom Bill offered a very formal type of interactivity, created and led by the party, and part of its purpose was promotional, it does provide an insight into how parties view interaction. In this example, the likely main target audience after the media are party activists who will directly respond, but also discuss it with their party colleagues offline. Therefore, interaction can snowball, where the target is not just those who see the message online, but also those they speak to offline. Interaction with the Freedom Bill took a number of forms. Visitors were encour- 
aged to interact through quizzes, to sign up for further information and to post their opinions publicly. The use of a Facebook group also implies horizontal communication between visitors. Collectively, we suggest that these interactive components can be classified as 'weak interaction', in that they involve contact between the party and visitors, but in a limited form. The Freedom Bill enhances the Liberal Democrats' relationship with online visitors, but the interaction it encourages is more akin to a consultative document than a face-to-face dialogue.

This case study illustrates how apparently limited take-up of online opportunities through 'weak interaction' can reflect underlying decisions about how a party should operate, as opposed to concerns of loss of control. We suggest that there are two main explanations for why parties may not fully explore the current participatory potential of Web 2.0 applications. First, the Liberal Democrat party hierarchy believe that their role is to promote their values, and consequently to persuade voters that they are the best party. This clearly implies a Downsian rational choice approach. As a consequence the Liberal Democrat headquarters reject what they view to be a more consumerist marketing approach of asking what citizens think, and constructing policies to meet these needs. Second, in terms of policy development, interaction with the wider public cannot override the importance of the formal internal policymaking processes. In addition to these two main reasons, parties are likely to ask a series of other questions such as: will interaction improve policy, will it help us win votes and how much of our finite resources will we need to expend to manage the process? Focusing on the issue from the perspective of the third party in UK politics, a position that permits experimentation and risk-taking, we suggest it is not simply about not allowing user-generated comment and content, as that is available online anyway. Nor is it about costing policy to the nth pound or promising to save the job of a specific voter. Academic commentators may see huge democratic and representational potential in Web 2.0 but, for political parties, 'weak interaction' is shaped by a more realistic world-view.

\section{Author contact details}

Darren G. Lilleker, Senior Lecturer, The Media School, Bournemouth University, Fern Barrow, Poole BH12 5BB, UK. E-mail: dlilleker@bournemouth.ac.uk

Mark Pack, Mandate Communications, 60 Great Portland Street, London WlW 7RT, UK. E-mail: Mark.Pack@YourMandate.com

Nigel Jackson, The School of Tourism and Hospitality, University of Plymouth, Cookworthy Building, Drake Circus, Plymouth PL4 8AA, UK. E-mail: nigel.jackson@plymouth.ac.uk

\section{Notes}

1 One of the authors, Mark Pack, was from 2001 to 2009 responsible for the Liberal Democrats' e-campaigning.

2 These targets were set by one of the authors, Mark Pack, in agreement with others in the Liberal Democrats.

3 This can be found at: http://freedom.libdems.org.uk/the-freedom-bill/13-public-interest-defence-forwhistleblowers/.

\section{References}

Bimber, B. (1998), 'The Internet and Political Mobilisation', Social Science Computer Review 16(4), pp. 391-401.

Coleman, S. (ed.) (2001), 2001: Cyber Space Odyssey - the Internet at the UK Election, •.•: Hansard Society. 
JOBNAME: No Job Name PAGE: 8 SESS: 12 OUTPUT: Mon Mar 1 18:21:28 2010

/v2451/blackwell/journals/PONL_v30_i2/ponl_1373

Coleman, S. (2005a), Direct Representation: Towards a Conversational Democracy. London: IPPR Exchange.

Coleman, S. (2005b), ‘New Mediation and Direct Representation: Reconceptualising Representation in the Digital Age', New Media and Society 7(2), pp. 177-198.

Garner, R. and R. Kelly (1998), British Political Parties Today (2nd edn), Manchester: Manchester University Press.

Gibson, R. and S. Ward (1997), 'UK Political Parties and the Internet: Prospects for Democracy', Working Papers in Contemporary History and Politics 13, European Studies Research Institute, University of Salford

Greengard, S. (2009), 'The First Internet President', Communications of the ACM 52(2), pp. 16-18.

Hindman, M. (2008), The Myth of Digital Democracy, Princeton, NJ: Princeton University Press.

Howard, P. (2006), New Media Campaigns and the Managed Citizen, Cambridge: Cambridge University Press.

Ingle, S. (2008), The British Party System (4th edn), Abingdon: Routledge.

Jackson, N. (2003), 'MPs and Web Technologies: An Untapped Opportunity?', Journal of Public Affairs 3(2), pp. 124-137.

Jackson, N. (2007), 'Political Parties, the Internet and the 2005 General Election: Third Time Lucky?' Internet Research 17(3), pp. 249-271.

Jackson, N. and D. Lilleker (2009a), 'Building an Architecture of Participation? Political Parties and Web 2.0 in Britain', Journal of Information Technology and Politics $\bullet \bullet$, pp. $\bullet \bullet-\bullet \bullet$.

Jackson, N. and D. Lilleker (2009b), 'MPs and E-Representation: Me, MySpace and I', British Politics 4(2), pp. 236-264.

Lusoli, W. and S. Ward (2005), 'Logging on or Switching Off?' in S. Coleman and S. Ward (eds.), Spinning

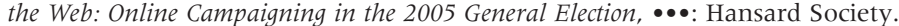

Margolis, M. and D. Resnick (2000), Politics as Usual: The Cyberspace Revolution, Thousand Oaks, CA: Sage.

Newell, J. (2001), 'New Parties, New Media: Italian Political Parties and the Web', Harvard International Journal of Press Politics 6(4), pp. 60-87.

Norris, P. (2000), A Virtuous Circle: Political Communications in Post-industrialised Societies, Cambridge: Cambridge University Press.

Norris, P. (2001), Digital Divide: Civic Engagement, Information Poverty and the Internet Worldwide, Cambridge: Cambridge University Press.

O'Reilly, T. (2005), 'What is Web 2.0', available at: http://www.oreillynet.com/pub/a/oreilly/tim/news/ 2005/09/30/what-is-web-20.html, accessed 12 September 2007.

Plasser, F. (2002), Global Political Campaigning, Westport, CT: Praeger Publishers.

Rheingold, H. (1993), The Virtual Community: Homesteading on the Electronic Frontier, Reading: AddisonWesley.

Schattschneider, E. (1942), Party Government, New York: Farrar \& Rinehart.

Sommer, M. (2003), 'Key Developments in American E-Politics and E-Activism: From Fundraising to Getting out the Vote', Paper presented at the Political Marketing Conference, Middlesex University 18-20 September.

Stirland, S. (2008), 'Propelled by Internet, Barack Obama Wins Presidency', Wired Magazine, 4 November, available at: http://www.wired.com/threatlevel/2008/11/propelled-by-in/, accessed 16 June 2009.

Stone, B. (1996), 'Politics 96', Internet World, November, pp. 40-50.

Stromer-Galley, J. (2000), 'Online Interaction and Why Candidates Avoid It', Journal of Communication 50(4), pp. 111-132.

Tedesco, J. (2007), 'Examining Internet Interactivity Effects on Young Adult Political Information Efficacy', American Behavioral Scientist 50(9), pp. 1183-1194.

Ward, S. and R. Gibson (1998), 'The First Internet Revolution? United Kingdom Political Parties and Campaigning in Cyberspace' in I. Crewe, B. Gosschalk and J. Bartle (eds.), Political Communication: Why Labour Won the Election of 1997, London: Frank Cass.

Ward, S. and W. Lusoli (2005), 'From Weird to Wired: MPs, the Internet and Representative Politics in the UK', Journal of Legislative Studies $11(1)$, pp. 57-81.

Williams, P., K. Tramell, M. Postelnicu, K. Landreville and J. Martin (2005), 'Blogging and Hyperlinking: Use of the Web to Enhance Visibility during the 2004 US Campaign', Journalism Studies 6(2), pp. 177-186. 
JOBNAME: No Job Name PAGE: 9 SESS: 12 OUTPUT: Mon Mar 1 18:21:28 2010

/v2451/blackwell/journals/PONL_v30_i2/ponl_1373

\begin{tabular}{|l|l|}
\hline \multicolumn{2}{|c|}{ Toppan Best-set Premedia Limited } \\
\hline Journal Code: PONL & Proofreader: Elsie \\
\hline Article No: 1373 & Delivery date: 1 March 2010 \\
\hline Page Extent: 8 & \\
\hline
\end{tabular}

\section{AUTHOR QUERY FORM}

Dear Author,

During the preparation of your manuscript for publication, the questions listed below have arisen. Please attend to these matters and return this form with your proof.

Many thanks for your assistance.

\begin{tabular}{|c|c|c|}
\hline $\begin{array}{c}\text { Query } \\
\text { References }\end{array}$ & Query & Remark \\
\hline q1 & $\begin{array}{l}\text { AUTHOR: Wright (2008) has not been included } \\
\text { in the Reference List, please supply full } \\
\text { publication details. }\end{array}$ & \\
\hline q2 & $\begin{array}{l}\text { AUTHOR: Stromer-Galley, } 2002 \text { has not been } \\
\text { included in the Reference List, please supply full } \\
\text { publication details. }\end{array}$ & \\
\hline q3 & $\begin{array}{l}\text { AUTHOR: Please check whether 'not' is correct } \\
\text { here or should be deleted. }\end{array}$ & \\
\hline $\mathrm{q} 4$ & $\begin{array}{l}\text { AUTHOR: Please provide the city location of } \\
\text { publisher for Coleman } 2001 \text {. }\end{array}$ & \\
\hline q5 & $\begin{array}{l}\text { AUTHOR: Howard, } 2006 \text { has not been cited in } \\
\text { the text. Please indicate where it should be cited; } \\
\text { or delete from the Reference List. }\end{array}$ & \\
\hline q6 & $\begin{array}{l}\text { AUTHOR: Please provide the volume no. and } \\
\text { page range for Jackson \& Lilleker 2009a. }\end{array}$ & \\
\hline q7 & $\begin{array}{l}\text { AUTHOR; Please provide the publisher location } \\
\text { for Lusoli \& Ward } 2005 .\end{array}$ & \\
\hline q8 & $\begin{array}{l}\text { AUTHOR: Please check this URL in Stirland } \\
2008 \text { and confirm that it is correct. (Please note } \\
\text { that it is the responsibility of the authors to } \\
\text { ensure that all URLs given in this article are } \\
\text { correct and useable.) }\end{array}$ & \\
\hline
\end{tabular}




\section{USING E-ANNOTATION TOOLS FOR ELECTRONIC PROOF CORRECTION}

\section{Required Software}

Adobe Acrobat Professional or Acrobat Reader (version 7.0 or above) is required to e-annotate PDFs. Acrobat 8 Reader is a free download: http://www.adobe.com/products/acrobat/readstep2.html

Once you have Acrobat Reader 8 on your PC and open the proof, you will see the Commenting Toolbar (if it does not appear automatically go to Tools>Commenting>Commenting Toolbar). The Commenting Toolbar looks like this:

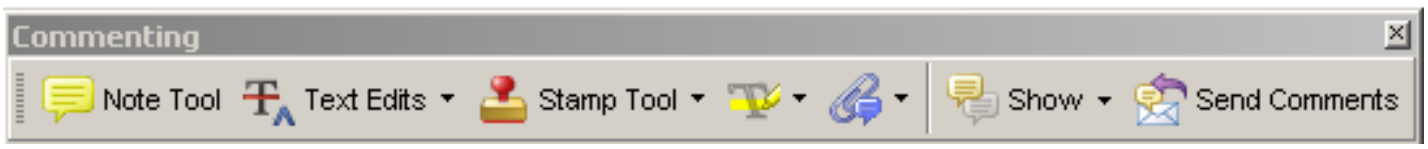

If you experience problems annotating files in Adobe Acrobat Reader 9 then you may need to change a preference setting in order to edit.

In the "Documents" category under "Edit - Preferences", please select the category 'Documents' and change the setting "PDF/A mode:" to "Never".

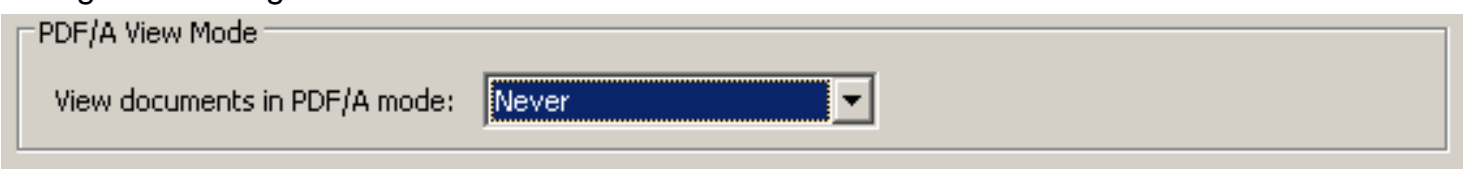

\section{Note Tool - For making notes at specific points in the text}

Marks a point on the paper where a note or question needs to be addressed.

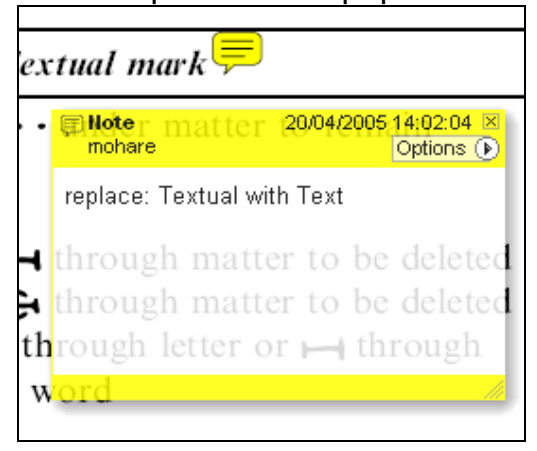

\section{How to use it:}

1. Right click into area of either inserted text or relevance to note

2. Select Add Note and a yellow speech bubble symbol and text box will appear

3. Type comment into the text box

4. Click the $X$ in the top right hand corner of the note box to close.

\section{Replacement text tool - For deleting one word/section of text and replacing it}

Strikes red line through text and opens up a replacement text box.

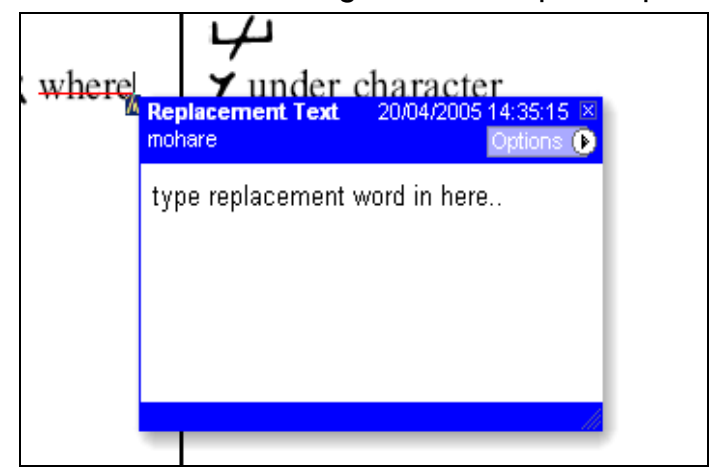
How to use it:
1. Select cursor from toolbar
2. Highlight word or sentence
3. Right click
4. Select Replace Text (Comment) option
5. Type replacement text in blue box
6. Click outside of the blue box to close

\section{Cross out text tool - For deleting text when there is nothing to replace selection}

Strikes through text in a red line.

\begin{tabular}{|l|}
\hline substitute part of one or \\
more word(s) \\
Change to italies \\
Change to capitals \\
Change to small capitals \\
\hline
\end{tabular}
How to use it:
1. Select cursor from toolbar
2. Highlight word or sentence
3. Right click
4. Select Cross Out Text 


\section{WILEY-BLACKWELL}

Approved tool - For approving a proof and that no corrections at all are required.

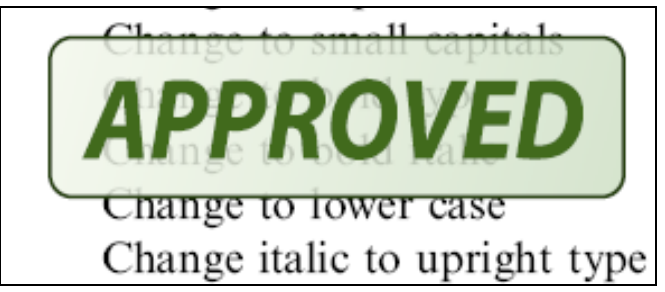

\section{How to use it:}

1. Click on the Stamp Tool in the toolbar

2. Select the Approved rubber stamp from the 'standard business' selection

3. Click on the text where you want to rubber stamp to appear (usually first page)

Highlight tool - For highlighting selection that should be changed to bold or italic. Highlights text in yellow and opens up a text box.

\begin{tabular}{|c|c|}
\hline & \\
\hline puble quotation & (As above) \\
\hline phen $\begin{array}{c}\text { Highlight } \\
\text { mohare }\end{array}$ & $\begin{array}{l}\text { 20:04:2005 14:45:47 } x \\
\text { Options (i) }\end{array}$ \\
\hline W par & \\
\hline parą & \\
\hline $\mathrm{se}$ & \\
\hline 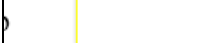 & \\
\hline ace $b$ & \\
\hline
\end{tabular}

\section{How to use it:}

1. Select Highlighter Tool from the commenting toolbar

2. Highlight the desired text

3. Add a note detailing the required change

Attach File Tool - For inserting large amounts of text or replacement figures as a files. Inserts symbol and speech bubble where a file has been inserted.

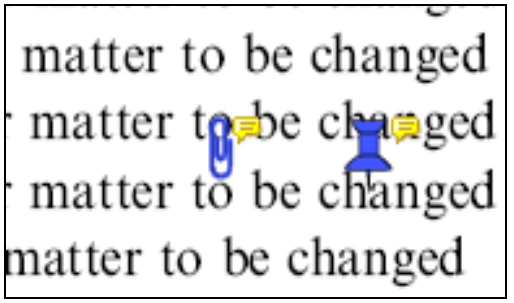

How to use it:

1. Click on paperclip icon in the commenting toolbar

2. Click where you want to insert the attachment

3. Select the saved file from your PC/network

4. Select appearance of icon (paperclip, graph, attachment or tag) and close

\section{Pencil tool - For circling parts of figures or making freeform marks}

Creates freeform shapes with a pencil tool. Particularly with graphics within the proof it may be useful to use the Drawing Markups toolbar. These tools allow you to draw circles, lines and comment on these marks.

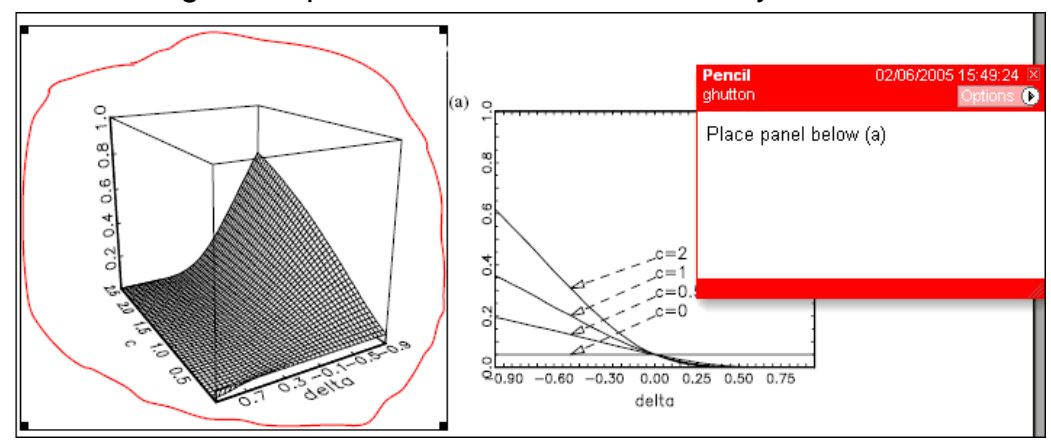

How to use it:

1. Select Tools $>$ Drawing Markups $>$ Pencil Tool

2. Draw with the cursor

3. Multiple pieces of pencil annotation can be grouped together

4. Once finished, move the cursor over the shape until an arrowhead appears and right click

5. Select Open Pop-Up Note and type in a details of required change

6. Click the $X$ in the top right hand corner of the note box to close. 
Help

For further information on how to annotate proofs click on the Help button to activate a list of instructions:

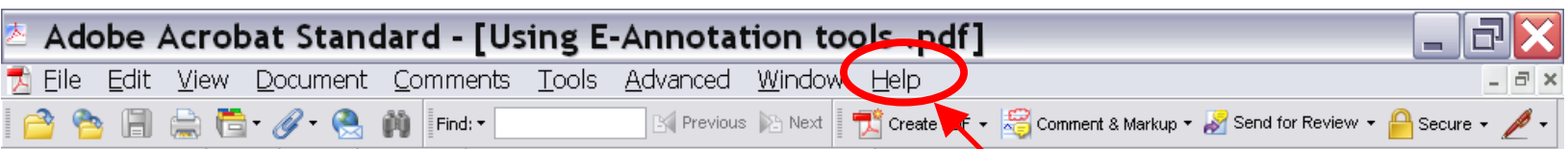

